\title{
KEKRISTENAN DAN NASIONALISME \\ DI INDONESIA
}

\section{Arthur Aritonang*}

\begin{abstract}
Abstrak: "Kekristenan dan Nasionalisme di Indonesia" membahas mengenai sejarah kekristenan di Indonesia yang diasumsikan sebagai agama yang pro terhadap penjajah dari Barat namun asumsi itu tidak benar sebagai bukti ada banyak tokoh Kristen yang ikut memperjuangkan kemerdekaan Indonesia dengan didasarkan semangat nasionalisme. Kemudian pasca-kolonial Belanda kekristenan ingin menampilkan wajah baru yang sungguh-sungguh keindonesiaan dengan lahirnya organisasi DGI/PGI. Namun seiring waktu ketika berakhirnya era orde baru dan memasuki era reformasi, kekristenan dan masyarakat lainnya di Indonesia menghadapi arus gelombang yang mengatasnamakan agama yang pergerakannya cukup masif dibandingkan di era orde lama diantaranya: kelompok Islam fundamentalis yang ingin menjadikan NKRI bersyariat Islam, adanya gerakan politik transnasional $\mathrm{HTI}$ yang ingin menghidupkan kembali kejayaan Islam pada abad ke-6 dan faham Wahabisme yang sarat dengan kekerasan. Persoalan lainnya ialah adanya kemiskinan yang terstruktur akibat dari krisis moneter yang melanda di Indonesia tahun 1997. Melalui masalah ini, setiap agamaagama di Indonesia harus melakukan konvergensi atas dasar keprihatinan yang sama.
\end{abstract}

Abstract: Christianity and Nationalism in Indonesia" discuss the history of Christianity in Indonesia, which is assumed to be a religion that is pro to Western colonialism. Still, this assumption is incorrect as evidence that many Christian figures fought for Indonesian independence based on the spirit of nationalism. Then post-colonial of Dutch, Christianity

* Penulis adalah mahasiswa program pascasarjana di Sekolah Tinggi Teologi Cipanas. Penulis dapat dihubungi melalui email: arthur.sttcipanas@yahoo.co.id. 
wanted to be presented a truly Indonesian face with the birth of the DGI / PGI organization. But over time when the end of the new order and entering the era of reform, Christianity and the other societies in Indonesia faced challenges in the name of religion whose movements were quite massive compared to the old order including fundamentalist Islamic groups who wanted to make the Republic of Syariat Muslim Indonesia, a transnational HTI political movement that wanted to revive the glory of Islam in the 6th century and the ideology of Wahhabism which is loaded with violence. Another problem is the existence of structured poverty due to the monetary crisis that hit Indonesia in 1997. Through this problem, every religion in Indonesia must converge on the basis of the same concerns.

Kata-kata Kunci: Kekristenan, nasionalisme, agama, politik, dan Pancasila.

\section{Latar Belakang Dan Konteks Masalah}

Dewasa ini kita hidup di era perbuahan yang sangat cepat di segala bidang. Perubahan ini bermula pada abad ke-17 dan ke-18 yang kita sebut sebagai abad revolusi industri dan abad pencerahan yang bermula di Eropa. Abad ini berkembang dan menyebar sangat cepat hampir di semua negara di dunia. Perubahan diawali dari kehadiran industri (teknologi), perubahan pola pikir manusia dari primitif (yang mempercayai sesuatu yang takhayul) berangsur-angsur menjadi lebih mengedepankan rasio, perubahan gaya hidup menjadi modern, perubahan dalam berelasi yang semula hidup secara kolektif sekarang cenderung individualistik, dan seterusnya.

Kemajuan zaman yang semula terjadi di negara Eropa dan Amerika berdampak bagi kesadaran masyarakat Indonesia di era kolonialisme. Melihat akan kemajuan yang sangat pesat di benua 
Eropa dan Amerika membuat masyarakat Indonesia menjadi sadar akan pentingnya membangun kesadaran nasionalisme sebagai bentuk perlawanan dari bangsa-bangsa penjajah. Pada masa itu masyarakat Indonesia merasa dirinya ditindas sehingga kehilangan hak untuk merdeka. Ada sebuah harapan besar bahwa ke depannya bangsa Indonesia bisa membangun negara ini untuk berkembang menjadi bangsa yang maju layaknya seperti negara-negara Barat lainnya. Singkatnya setelah Indonesia mencapai kemerdekaan sampai memasuki era reformasi ada sebuah gerakan transnasional yakni aktivitas politik-keagamaan yang berasal dari Timur Tengah yang masuk ke Indonesia yang ingin melakukan politik penyeragaman agama di Indonesia.

Menurut Einar M. Sitompul fakta kemajemukan Indonesia merupakan bagian integral dari kemajemukan dunia akibat globalisasi. Kemajemukan dalam semua sektor (agama, budaya, tradisi, dan adat serta gaya hidup) akibat globalisasi, masyarakat yang berbeda latar belakang saling terkait sebagai suatu jaringan. Fakta sosial ini harus disikapi dengan positif sehingga kemajemukan harus diterima dan tidak mungkin dihindari. ${ }^{1}$

1. Einar M. Sitompul, "Meningkatkan Peran Sosial Gereja”, dalam Konteks Kemajemukan dan Global," dalam Perjalanan Sarat Muatan Buku 1 - Pdt. Dr. Einar Sitompul, peny. Hotman Siahaan, SM Parulian Tanjung (Jakarta: Unit Publikasi dan Informasi STT Jakarta berkerjasama dengan HKBP Menteng, 2014), 25-26. 


\section{Nasionalisme dan Sejarahnya di Era Kolonialisme}

Apa itu nasionalisme? kesadaran semua anggota untuk hidup bersatu di dalam suatu negara merdeka. ${ }^{2}$ Percakapan mengenai nasionalisme di Indonesia bermula pada abad ke-20. Tahun 1900-an telah memperlihatkan munculnya nasionalisme yang berhubungan dengan kolonialisme. Nasionalisme adalah reaksi dan penolakan terhadap kolonialisme. ${ }^{3}$

Bagaimana awal mula masyarakat Indonesia mempunyai kesadaran akan nasionalisme dan di manakah peran Gereja secara institusional maupun non-institusional sepanjang perjuangan merebut kemerdekaan Indonesia? Sebelum lebih lanjut kepada uraian-kronologis mengenai kiprah warga Indonesia dalam memperjuangkan terwujudnya NKRI, namun perlu diketahui keberadaan gereja secara institusional di era kolonialisme. Sejarah mencatat banyak gereja di era kolonialisme dipimpin oleh misionarismisionaris Eropa, sedangkan pendeta-pendeta pribumi yang jumlahnya terbatas hanya pembantu mereka saja. Di sisi lain, pandangan teologi yang umumnya dianut oleh gereja di masa itu adalah pietis dengan pemahaman iman dan kehidupan Kristen yang terlalu bersifat pribadi serta rohani dan terarah kepada alam di seberang maut. Ketidakmampuan gereja-gereja permulaan itu untuk

2. Einar M Sitompul, "Dinamika Islam di Indonesia", Model Perjumpaan dengan Umat Islam," dalam Misi Baru dalam Kemajemukan Teologi Lintas-Iman dan Lintas-Budaya Buku Penghormatan 80 Tahun Prof. Dr. Olaf Schumann (Tomohon: UKIT Press, 2018), 24.

3. T. B. Simatupang, Iman Kristen dan Pancasila (Jakarta: BPK Gunung Mulia, 1985), 23. 
menjawab tantangan zaman baru, tetapi tidak menghalangi anggotaanggotanya secara perorangan untuk menggabungkan diri pada gerakan nasionalisme tadi. ${ }^{4}$ Teologi pietisme gereja-gereja di Indonesia pada waktu itu dipertanyakan oleh masyarakat nonMuslim yang berkata apakah usah pekabaran Injil itu hanya sekedar alat ekspansi Barat? Di saat yang sama juga, mendapatkan kritik dari tokoh-tokoh Kristen pada waktu itu sebut saja Prof. T. S. G. Mulia, dan Dr. J. Leimena. Mereka mengkritik bahwa tugas orang Kristen bukan hanya memberitakan Injil, melayani Sakramen dan sebagainya. Tetapi gereja harus ikut serta dalam pembaharuan masyarakat. $^{5}$

Sejalan dengan pertanyaan sebelumnya mengenai kesadaran nasionalisme yang mulai ada di hati masyarakat Indonesia? Munculnya gerakan-gerakan nasionalisme pada abad ke-19 dipicu oleh semangat anti-kolonialisme yang berkepanjangan. Beberapa pemberontakan (paling tidak dari kacamata Belanda) seperti yang dilakukan oleh Pangeran Diponegoro, Tuanku Imam Bonjol (1850), Perang Padri, Perang Pattimura dan sebagainya harus dianggap sebagai permulaan timbulnya perasaan nasionalisme. ${ }^{6}$ Meskipun perjuangan nasionalisme pada waktu itu masih bersifat kedaerahan (cultural nation) yang berdasarkan kesatuan etnis namun pada dasarnya, kerajaan-kerajaan di Nusantara menolak adanya pihak

4. Simatupang, Iman Kristen dan Pancasila, 25.

5. Simatupang, Iman Kristen dan Pancasila, 27.

6. Andreas A. Yewangoe, Agama dan Kerukunan (Jakarta: BPK Gunung Mulia, 2002), 10-11. 
asing (penjajah) dari luar Nusantara yang keberadaannya sangat meresahkan kerajaan-kerajaan yang ada di Nusantara ini.

Kedua, setelah berakhirnya masa k erajaan di Nusantara terjadi kebangkitan kesadaran kaum intelektual Bumiputera akan pentingnya persatuan nasional menjadi pemicu kesadaran kebangsaan Indonesia masa itu, meskipun saat itu negara Indonesia merdeka belum terbentuk. Suasana keprihatinan dan keterbelakangan mayoritas kaum pribumi mendorong kalangan intelektual untuk mengorganisasi diri dalam payung kebangsaan. Berdirinya Budi Utomo pada 20 Mei 1908, sebagai organisasi modern pertama di Indonesia, menandai kebangkitan kesadaran kebangsaan Indonesia itu. Perkumpulan ini bertujuan untuk meningkatkan martabat rakyat dan bangsa melalui pendidikan karena dilatarbelakangi dari suasana keprihatinan dan keterbelakangan mayoritas kaum pribumi. $^{7}$ Ketiga, pada tahun 1912 dibentuknya perkumpulan berdasarkan Islam yang bernama Sarekat Islam (SI) atau (mengalami perubahan nama) yang dulunya bernama Sarekat Dagang Islam (SDI) yang didirikan oleh Hadji Samanhudi (dibentuknya tahun 1905). Tujuan dari organisasi ini ialah memperhatikan saudara dan pengusaha Indonesia. Kemudian pada tahun 1920, gabungan Sarekat Islam Merah dan Sarekat Rakyat, lahirlah Partai Komunis Indonesia (PKI) dalam pimpinan Semaun, Darsono, Muso, dan lain-

7. Y. Ari Nurcahyo, "Pascanasionalisme, Pascalndonesia Meneropong Masa Depan Nasionalisme", dalam Meneropong Indonesia 2020 Pemikiran dan Masalah Kebijakan (Jakarta: Soegeng Sarjadi Syndicated, 2004), 6. 
lain. PKI membuat siasat melenyapkan kekuasaan Belanda. Kaum buruh sangat dipengaruhinya untuk melakukan pemogokan pada 1923. Singkatnya pada tahun 1926 timbul pemberontakanpemberontakan terutama di Jawa Barat dan Sumatera Barat. Belanda berhasil memadamkannya, sebagian besar yang ikut aksi pemberontakan tersebut diasingkan di tengah-tengah rimba raya Irian Jaya. Kekuatan kaum ekstremis sudah dipatahkan oleh kekuasaan Belanda. ${ }^{8}$ Tekanan-tekanan pihak Kolonial yang dihadapi oleh kaum pergerakan nasional masa itu malah mendorong aksi-aksi penggalangan yang jauh lebih besar. Aksi penggalangan nasional ini memuncak pada penyelenggaraan kongres Pemuda dari seluruh Indonesia pada 28 Oktober $1928 .{ }^{9}$ Salah seorang tokoh pemuda yaitu Amir Syarifudin Harapan (Tokoh Kristen dan Pemuda Nasionalis) mencetuskan Sumpah Pemuda, dan membentuk organisasi nasional lainnya. ${ }^{10}$ Bunyi Sumpah pemuda sebagai berikut: Kita putera dan puteri Indonesia berbangsa satu, Bangsa Indonesia; Kita putera dan puteri Indonesia bertanah air satu, Tanah Air Indonesia; Kita putera dan puteri Indonesia, berbahasa satu, Bahasa Indonesia. ${ }^{11}$ Singkatnya, dampak dari pergerakan aksi nasional pemuda Indonesia kemudian terus berlanjut sampai pada 1 Juni 1945 di mana Soekarno

8. Hutauruk, Gelora Nasionalisme Indonesia (Jakarta: Erlangga, 1984), 16-18.

9. Nurcahyo, Pascanasionalisme, Pascalndonesia," 7.

10. Zakharia J. Ngelow, Kekristenan dan Nasionalisme Perjumpaan Umat Kristen Protestan dengan Pergerakan Nasional Indonesia 1900-1950 (Jakarta: BPK Gunung Mulia, 1996), 172.

11. Hutauruk, Gelora Nasionalisme Indonesia, 18. 
mengucapkan usul-usulnya mengenai dasar negara pada rapat BPUPKI dikenal sebagai pidato "Lahirnya Pancasila". [Saat itu Jepang membantu bangsa Indonesia untuk segera mendeklarasikan kemerdekaan dari pengaruh Belanda meskipun dibalik dukungannya untuk Indonesia ada motif politik dan ekonomi di dalamnya] Setelah itu lahirlah suatu panitia bantu yakni Panitia Sembilan berhasil dalam mencapai rumusan konsep Piagam Jakarta. Piagam ini memuat versi Pancasila yang memberi hak khusus kepada pihak Islam: Sila Ketuhanan diikuti "tujuh kata": "dengan kewajiban menjalankan syariat Islam bagi pemeluk-pemeluknya." Rumusan ini diterima untuk disahkan menjadi Pembukaan UUD oleh Panitia Persiapan Kemerdekaan Indonesia (PPKI) sebagai badan pengganti BPUPKI yang dibentuk pada tanggal 7 Agustus 1945. Atas dasar para pemuda militan dan dengan dukungan Laksamana Maeda, proklamasi kemerdekaan Indonesia dicanangkan oleh Soekarno-Hatta pada 17 Agustus 1945, dua hari setelah Jepang menyerah tanpa syarat atas Amerika Serikat dan Sekutunya. ${ }^{12}$

Hari itu juga, Hatta dihubungi oleh kalangan Kristen dari Indonesia bagian Timur terhadap bagian rumusan konsep Pembukaan UUD yang mengistimewakan golongan Islam. Hatta menanggapi secara serius soal itu, lalu keesokan paginya, sebelum sidang PPKI, Hatta berunding dengan beberapa tokoh Islam hal itu

12. Ngelow, Kekristenan dan Nasionalisme, 47. 
demi mencegah perpecahan nasional. Akhirnya disepakati mengganti "tujuh kata" itu menjadi "Ketuhanan Yang Maha Esa". ${ }^{13}$

\section{Nasionalisme Pasca Kemerdekaan}

Pada rezim Soeharto di masa Orde Baru semangat untuk membangun politik keagamaan tidak kuat. ${ }^{14}$ Kelompok organisasi Islam mengalami tekanan politik dan tidak diberi kesempatan terjun dalam arena perpolitikan Indonesia. ${ }^{15}$ Tidak hanya bagi kelompok Islam, kekristenan di Indonesia juga mengalami tekanan dari rezim Soeharto di tengah-tengah kesesakan dan himpitan peraturanperaturan "pembatas" gerak bagi umat Kristen-antara lain izin mendirikan gereja dan larangan menerima bantuan ahli dari luar negeri, namun tokoh-tokoh Victor Matondang, Sabam Sirait, Bungaran Saragih, Yewangoe, dan beberapa lainnya itu terus merangsek dengan suara kenabiannya. Pemerintahan Soeharto yang semakin solid-terutama pada periode akhir masa jabatannya (19931998)-telah benar-benar melumpuhkan gereja. ${ }^{16}$ Melihat akan iklim politik yang tidak sehat dan kondusif, mengundang sebuah pergerakan masa yang sangat besar menuntut agar Soeharto

13. Ngelow, Kekristenan dan Nasionalisme, 48.

14. Masykuri Abdillah, Islam dan Dinamika Sosial Politik di Indonesia (Jakarta: PT Gramedia, 2011), 80.

15. Richard Daulay, Keterlibatan Umat Kristen di Tengah Kehidupan Sosial Politik di Indonesia, 1.

16. Antie Solaiman, "Teologi dan Nation Building: Gereja dan Pembenahan Sosial", dalam Peran Kristen dalam Membangun Masyarakat Sipil, ed. Victor Silaen (Jakarta: Pustaka Tangga, 2003), 7. 
mengundurkan diri dari jabatan sebagai Presiden RI, kemudian dilanjutkan oleh Wakil Presiden B. J. Habibie sebagai Presiden RI sebagai bentuk mengakhiri rezim Orde Baru dan memasuki era baru yang disebut Reformasi.

Pelantikan Habibie sebagai Presiden RI ketiga segara menimbulkan pro-kontra masyarakat luas yang secara umum dapat dikategorikan sebagai polarisasi antara kelompok nasionalis kontra kelompok Islamis yaitu kelompok yang berjuang untuk menjadikan Indonesia menjadi negara atau menganut sistem Islam. Pihak Politik Islam melihat sosok Habibie sebagai tokoh yang dekat dengan Islam. ${ }^{17}$ Era reformasi dan demokrasi yang sedang bergulir memberikan peluang bagi seluruh elemen masyarakat untuk mengekspresikan dan memperjuangkan agenda politik. Salah satu komponen bangsa yang merasa sangat diuntungkan dengan era baru ini adalah kelompok Islam politik, yaitu golongan Islam yang sejak awal kemerdekaan Indonesia menghendaki agar Indonesia dijadikan menjadi negara Islam. ${ }^{18}$ Sadar bahwa usaha memasukkan Piagam Jakarta melalui amandemen UUD 1945 berkali-kali membentur tembok, kubu prosyariat menggeser fokus pertarungan dari tingkat pusat ke daerah. Memanfaatkan celah UU Otonomi Daerah, kubu pengusung syariat sukses mengegolkan peraturan daerah tentang syariat di beberapa wilayah. Modusnya hampir sama, menjalin aliansi

17. Richard Daulay, Kekristenan dan Politik (Jakarta: Waskita, 2011), 102.

18. Daulay, Kekristenan dan Politik, 103. 
taktis dengan calon kepala daerah dari pelbagai macam partai dan dijanjikan dukungan melimpah dari pemilih muslim. ${ }^{19}$ Era reformasi semasa pemerintahan presiden Habibie, upaya untuk mendorong terwujudnya masyarakat madani ketika itu sangat kuat di Indonesia 20

Melihat dari konteks sejarahnya masyarakat madani bahwa Nabi Muhammad adalah tokoh yang membangun sebuah komunitas di Madinah, namun ia tidak pernah menyuarakan tentang perlunya membangun satu tatanan pemerintahan yang harus dipedomani oleh umatnya. Nabi juga tidak pernah memerintahkan kepada para penerusnya untuk membuat satu kompas sistem politik tertentu. ${ }^{21}$

Menurut hemat penulis, keberadaan produk hukum agama di Indonesia justru tidak sejalan dengan hukum tertinggi di Republik Indonesia ini yakni Pancasila, UUD'45. Melihat akan kondisi semacam ini, Negara bisa dinyatakan gagal karena membiarkan produk hukum agama untuk mengatur sistem kehidupan masyarakat pluralis. Sistem itu mendiskriminasi masyarakat yang bukan Islam dan merampas hak masyarakat sipil yang berbeda agama dalam menjalankan ibadah dan mendirikan rumah Ibadah.

19. Jeffrie Geovanie, Civil Religion Dimensi Sosial Politik Islam (Jakarta: PT Gramedia Pustaka Utama, 2013), xi.

20. Masykuri Abdillah, Islam dan Dinamika Sosial Politik, 81.

21. Abd Moqsith Ghazali, "Demistifikasi Kepemimpinan Politik Muhammad SAW," Buletin Postra Islam, Politik, dan Demokrasi, JuliAgustus, 2002, 99. 
Fenomena lainnya yang menghinggapi di era pasca kejatuhan Orde Baru yang paling mencolok yakni kehadiran Hizbut Tahrir Indonesia (HTI). Meskipun sebelumnya HTI, yang sejak lebih dari 20 tahun lalu memperjuangkan khilafah di Indonesia, menyebut ada lebih dari 50 negara yang bisa dijadikan satu kepemimpinan di bawah bendera khilafah. Barangkali gerakan Islam saat ini yang paling fokus terwujudnya khilafah Islamiyah di Indonesia dan belahan dunia mana pun adalah Hizbut Tahrir. Hizbut Tahrir adalah sebuah gerakan Islam baru dalam percaturan politik nasional, organisasi ini menganggap politik sebagai aktivitasnya dan Islam sebagai mazhabnya. HTI berpendirian harus dilakukan melalui negara, dalam hal ini Hizbut Tahrir menekankan pada Daulah Islamiyah atau Daulah Khilafah yang dipimpin oleh seorang Khilafah yang dipilih secara demokrasi oleh rakyat. Karena itu HTI berusaha untuk mengembalikan posisi umat Islam ke masa kejayaan dan kemuliaan dulu. ${ }^{22}$ Kelompok HTI jelas menolak konsep kenegaraan (nation-state). HTI bercita-cita ingin membuat lembaga politik yang bersifat tunggal berskala internasional (global) untuk mengumpulkan seluruh masyarakat muslim di seluruh dunia dan kemudian mereka mengikatkan diri pada satu sistem payung hukum sama yang disebut hukum Islam. Lembaga politik ini disebut kekhalifahan yang dipimpin seorang khilafah yang terpilih.

22. Jonkennedi, Gerakan Hizbut Tahrir dan Realitas Politik Islam Kontemporer di Indonesia, Jurnal Komunika Vol. 6 No. 1 (Januari-Juni 2012), 2 
Di sisi lain, dalam pandangan $\mathrm{HTI}$, kekuatan-kekuatan Islam harus membangkitkan kembali umat Islam dari kemerosotan dalam berbagai dimensi kehidupan. Artinya, negara-negara muslim sudah banyak meniru pola kehidupan masyarakat Barat (ilmu pengetahuan, gaya hidup dan teknologi) yang tidak Islami atau tidak mengadopsi sistem hukum yang bersumber dari Islam. Kondisi semacam inilah menurut HTI harus diperhatikan oleh kekuatan-kekuatan Islam agar pemerintahan dikendalikan dengan sistem hukum Islam dan menentang segala bentuk pikiran-pikiran yang kufur. $^{23}$

Ali Abdurraziq (tokoh pemikir dan pembaharu Islam di Mesir), ia mempunyai pandangan yang berbeda dengan HTI. Islam tidak mempunyai kaitan apapun dengan sistem pemerintahan kekhalifahan. Kekhalifahan termasuk al-Khulafa al-Rasyidun, bukanlah sebuah sistem politik keagamaan atau keislaman, tetapi sebuah sistem yang duniawi. Menurutnya, kekhalifahan sebagai suatu instrumen untuk menjalankan otoritas ilahi, tidaklah inheren (berhubungan) dalam Islam sebagai sistem agama. Argumen utama Ali Abdurraziq adalah bahwa kekhalifan tidak mempunyai dasar baik dalam al-Quran maupun al-Hadits. Kedua sumber Islam ini tidak menyebut istilah khilafah dalam pengertian kekhilafahan yang pernah ada dalam sejarah. Lebih dari itu, tidak ada petunjuk yang jelas dalam Al-Quran maupun Hadits yang menentukan suatu sistem politik (sistem negara) untuk didirikan oleh umat Islam. ${ }^{24}$

23. Jonkennedi, Gerakan Hizbut Tahrir., 3

24. Ghazali, “Demistifikasi Kepemimpinan,” 94. 
Islam tidak menetapkan suatu rezim pemerintahan bahwa tidak pula mendesakkan kepada kaum muslimin suatu sistem pemerintahan tertentu lewat mana mereka harus diperintah; tapi Islam telah memberikan kita kebebasan mutlak untuk mengorganisasikan negara sesuai dengan kondisi-kondisi intelektual, sosial, ekonomi yang kita miliki dan dengan mempertimbangkan sosial dan tuntutan zaman. ${ }^{25}$

Menurut Ali Abdurraziq, Nabi Muhammad adalah sematamata utusan Tuhan, yang tugas pokoknya ialah menyampaikan risalah kenabian yang mengandung ajaran-ajaran moral kepada umat manusia, bukan seorang kepala negara atau pemimpin politik demi tujuan-tujuan politik kekuasaan. Seorang Nabi boleh saja menjalankan kekuasaan politik yang dibutuhkan oleh lingkunganlingkungan khusus zamannya; akan tetapi tindakan politiknya itu tidak dapat diambil sebagai petunjuk bahwa hal itu merupakan misi religiusnya. Islam sendiri tidak menyerukan pada adanya satu pemerintahan pada tingkat dunia yang dikelompokkan pada suatu kesatuan politik. Sebab, disamping bertentangan dengan karakter dasar manusia, juga tidak selaras dengan kehendak Tuhan. ${ }^{26}$

Pemerintahan Presiden Joko Widodo berhasil membubarkan HTI melalui perubahan Hukum dari UU/17/2013 ke perppu 2/2017. Meski pun secara hukum organisasi ini telah bubar, namun roh HTI

25. Ghazali, “Demistifikasi Kepemimpinan," 94.

26. Ghazali, “Demistifikasi Kepemimpinan," 97-98. 
masih terus berkeliaran untuk mempengaruhi umat Islam untuk memperjuangkan terwujudnya khilafah di bumi Indonesia.

Persoalan berikutnya, kehadiran faham keagamaan yang cukup ekstrem yang belakangan ini terjadi di Indonesia pasca reformasi ialah faham Wahabisme. Dalam sebuah acara yang digelar oleh salah satu Pengurus Wilayah GP Ansor di kawasan Sumatera, Ketua Umum PBNU, KH. Said Aqil Siradj dengan tegas mengatakan bahwa Wahabisme merupakan ancaman yang cukup berbahaya bagi kelangsungan NKRI (Negara Kesatuan Republik Indonesia). Meskipun kaum Wahabis bukan termasuk teroris, namun Wahabisme telah menyediakan landasan teologis yang cukup kuat bagi munculnya aksi-aksi terorisme kekerasan lainnya. ${ }^{27}$

Kurang lebih isi dari doktrin-doktrin Salafi-Wahaby ini adalah: pertama, doktrin tasyrik ini misalkan membuat larangan agar umat Islam tidak boleh mengangkat manusia, baik yang masih hidup maupun sudah meninggal, untuk dijadikan perantara dengan maksud mendekatkan diri kepada Allah. Kemudian juga tidak boleh meminta pertolongan atau tawassul kepada para wali dan orang saleh. Begitu pula kita tidak boleh ziarah ke makam-makam orang saleh dan para Nabi untuk meminta doa, juga tidak boleh mensakralkan semua itu. Apabila seorang muslim melakukan semua perkara-perkara yang telah disebutkan di atas, maka orang tersebut sudah termasuk

27. Ahmad Shidqi, Respons Nahdlatul Ulama (NU) terhadap Wahabisme dan Implikasinya bagi Deradikalisasi Pendidikan Islam, Jurnal Pendidikan Islam, Volume II no. 1 (Juni 2013): 110. 
sebagai orang musyrik dan atau kafir sehingga halal atau bahkan wajib diperangi. Kedua, Konsep yang kerap mewarnai doktrin-doktrin kaum Wahabi adalah apa yang disebut dengan bid'ah. Bid'ah menurut kaum Wahabi adalah praktik-praktik keagamaan yang tidak ada dasarnya dalam Al-Quran dan Sunnah serta otoritas sahabat Nabi. Termasuk di dalamnya yang mengikuti secara konsisten salah satu dari empat mazhab fikih. Selain itu praktik-praktik keagamaan yang dikategorikan sebagai bid'ah oleh Wahabi adalah memperingati hari kelahiran Nabi Muhammad SAW atau yang biasa dikenal dengan "Maulid Nabi" lalu praktik-praktik memperingati kematian seseorang atau tahlilan dalam rangka kematian seseorang itu termasuk bid'ah. ${ }^{28}$

Penulis mengamati sejak era reformasi bergulir, demokrasi di negara Indonesia tidak berjalan pada track yang tepat. Mengapa demikian? Sebab demokrasi yang diperlihatkan di ruang publik adalah demokrasi yang sebebas-bebasnya alias kebablasan yang menabrak aturan yang berlaku artinya demokrasi yang mengabaikan asas kemanusiaan dan keadilan sehingga munculnya gerakan untuk mewujudkan khilafah dan maraknya kelompok intoleran yang anti terhadap kemajemukan agama di Indonesia. Oleh sebab itu demokrasi dapat berjalan pada track yang benar jika ada pemimpin negara/daerah yang dengan tegas untuk memberlakukan penegakkan hukum yang sesuai dengan undang-undang yang berlaku sehingga di negara Indonesia ada ketertiban dan keteraturan.

28. Shidqi, Respons Nahdlatul Ulama 114-115. 
Selain pertikaian tentang perubahan sistem dasar negara, faham keagamaan yang berpotensi menghasilkan kekerasan bernuansa agama yang dapat mengancam kemajemukan hidup berbangsa, dan hadirnya perda-perda bersyariat, Indonesia juga dihadapkan dengan persoalan lainnya yaitu kemiskinan. Krisis moneter yang menimpa Indonesia di tahun 1997 mengakibatkan kemiskinan sebagai luka sosial yang masih terus menjadi kenyataan kekinian Indonesia. ${ }^{29} \mathrm{Di}$ samping itu, sejak runtuhnya Orde Baru, orang menyadari di balik pemerintahan yang kuat malah penuh KKN (Korupsi, kolusi dan nepotisme), akhirnya membawa malapetaka berkepanjangan bagi bangsa dan rakyat. ${ }^{30}$

Bagaimana respons gereja terhadap masalah sosial di Indonesia? gereja pasca-reformasi dapat disebut sebagai gereja yang multi-wajah. Ada gereja yang dengan giat berpartisipasi dalam gerakan perubahan di tengah masyarakat dengan upaya terstruktur yang bermitra dengan lembaga-lembaga agama lain dan pemerintah di luar gereja. Namun di sisi lainnya, ada gereja yang berbeda haluan dengan gereja sebelumnya yang melihat bagaimana gereja-gereja di Indonesia ternyata lebih banyak menekankan pelayanan sosial untuk kehidupan masa kini di dunia daripada pekabaran Injil untuk keselamatan jiwa dan kehidupan kekal, maka mudah saja mereka

29. Ebenhaizer Nuban Timo, "Nasionalisme Indonesia: Sebuah Kajian Antropologis-Historis mengenai Partisipasi Gereja dalam Mengisi dan Mengkritisi Pergerakan Nasional Indonesia", Jurnal Humaniora Yayasan Bina Darma Vol. III No. 3 (September 2014): 81.

30. Einar M. Sitompul, "Warga Gereja dalam Kehidupan Bernegara", dalam Perjalanan Sarat Muatan Buku 1 - Pdt. Dr. Einar Sitompul, 33. 
menuduh bahwa gereja-gereja telah meredusir (mengurangi) Injil Kristus yang diperuntukkan bagi keselamatan jiwa manusia dan kehidupan kekal menjadi hanya sebagai "Injil Sosial" untuk mengobati pelbagai penyakit dan permasalahan dalam masyarakat yang berlangsung hanya untuk sementara saja, seperti kemiskinan, ketidakadilan dan sebagainya. Sebaliknya, mereka amat mendesak pemahaman dan keyakinan mereka bahwa "penyakit-penyakit sosial" hanya dapat diatasi dengan pertobatan dan penerimaan hidup baru di dalam Yesus Kristus, bukan dengan pelbagai analisis dan pelayanan sosial, baik yang karitatif maupun yang struktural. Jadi menurut mereka gereja-gereja seharusnya lebih gencar dan kuat lagi, dengan segala cara apa pun, mengabarkan Injil untuk menyiapkan dunia ini bagi Kristus yang segera akan datang. ${ }^{31}$

Menurut penulis bahwa keselamatan masa kini sama pentingnya dengan keselamatan di masa mendatang artinya misi penginjilan harus bersifat holistik dan tidak boleh berat sebelah. Sehubungan dengan keselamatan masa kini jika melihat konteks Perjanjian Lama, pada abad ke-8 sM disebut sebagai bab baru dalam perjuangan para nabi demi terwujudnya keadilan sosial. Bukan dalam arti raja tidak lagi dikritik nabi, sebab Amos (7:11) dan Yeremia (22:13-19) tetap menjadikan raja sebagai alamat serangan yang tajam, bila ia menyeleweng. Melihat akan ketidakadilan yang terjadi

31. loanes Rakhmat, "Di Tengah Arus Fundamentalisme dalam Gereja," dalam Fundamentalisme Agama-Agama dan Teknologi (Jakarta: BPK Gunung Mulia, 1992), 33-35. 
di Israel, Tuhan akan bicara khususnya melalui Nabi Amos dan Mikha. Suatu masyarakat yang sampai kini relatif makmur dan terjamin diancam oleh kelompok kapitalisme. Perubahan tadi tidak hanya membawa akibat finansial bagi bekas petani kecil, tetapi seluruh kedudukan dan martabat mereka sebagai orang merdeka dalam masyarakat dan dalam ibadah hilang. Dengan latar belakang ini tidak aneh lagi, jika bahasa nabi-nabi begitu kasar dan emosional. Nabi Amos menolak sikap Israel itu, sikap yang munafik seakan-akan manusia dapat menipu Yahwe dengan perayaan ibadah dan korban bakaran dan sajian persembahan umat Israel atas nama Tuhan. Sebab ibadah yang dituntut Tuhan dari pada bangsa-Nya ialah keadilan dan kebenaran. ${ }^{32}$ Penulis memberikan catatan kritis bagi gereja secara organisasi maupun pribadi. Bahwa Alkitab memperlihatkan bahwa nabi-nabi Perjanjian Lama lebih banyak memperjuangkan keadilan dan kebenaran dari pada berdiam diri di Bait Allah.

\section{Kekristenan dan Nasionalisme di Indonesia}

Kekristenan (agama Kristen) bukanlah agama yang baru datang di negara ini, namun jauh sebelum Indonesia memproklamasikan kemerdekaan agama Kristen sudah ada bahkan dengan beberapa kehadiran gereja di Indonesia sudah menyesuaikan dengan konteks

32. W. Van Der Weiden, "Kritik Sosial dari Nabi-nabi Israel", dalam Aspek-Aspek Teologi Sosial ed. J. B. Banawiratma (Yogyakarta: Kanisius, 1988), 58-66. 
budaya lokal yang ada di bumi Indonesia seperti HKBP, GKE, HKI, KGPM dan GPM. Maka jika kita membahas mengenai kekristenan dalam mengisi nasionalisme Indonesia maka kita perlu menelisik kiprah kekristenan dalam sejarah perkembangan di Indonesia.

Pada tahun 1950-an disebut tahun-tahun kritis bagi bangsa ini. Pada tahun-tahun itu berbagai pemberontakan yang bersifat kedaerahan marak. Dengan munculnya pemberontakanpemberontakan itu seakan-akan bangsa Indonesia sedang diuji, apakah mampu memperlihatkan jati diri sebagai "bangsa Indonesia" atau justru runtuh berantakan. Di tengah pergumulan-pergumulan mewujudkan kebangsaan yang utuh itu, "Dewan Gereja-gereja di Indonesia" justru dibentuk pada 25 Mei 1950. gereja-gereja yang tergabung di dalamnya adalah gereja-gereja dengan latar belakang kesukuan yang kental dan latar belakang teologi dan eklesiologi. ${ }^{33}$ gereja-gereja di Indonesia yang dicirikan sebagai gereja-gereja suku keluar dari isolasi kedaerahan dan kesukuan untuk ambil bagian dalam pergerakan nasionalisme, yakni mengisi kemerdekaan pemberian Tuhan kepada bangsa Indonesia. Tugas untuk berpartisipasi dalam pembangunan bangsa hanya bisa dilakukan kalau gereja-gereja suku tadi berani membongkar mentalitas perkampungan (eksklusif) Kristen benteng yang membuat gereja teraliansi dari lingkungan sekitarnya. ${ }^{34}$

33. Andreas A. Yewangoe, Allah Mengizinkan Manusia Mengalami Diri-Nya Pengalaman dengan Allah dalam Konteks yang Berpancasila (Jakarta: BPK Gunung Mulia, 2018), 195.

34. Timo, "Nasionalisme Indonesia," 74. 
Semula didirikan PGI untuk mewujudkan adanya Gereja Kristen yang Esa di Indonesia. Namun perjalanan waktu, dalam memikirkan kesatuan yang hendak diwujudkan oleh PGI, para pemimpin gereja menyadari bahwa bukan kesatuan dalam tata aturan, liturgi dan pengakuan iman melainkan kesatuan dalam kesaksian (marturia) dan pelayanan (diakonia). Kesatuan gereja-gereja di Indonesia harus dinampakkan pada komitmen dan pelayanan sosial kemanusiaan. Seturut tendensi, Sidang Raya di Pemantang Siantar (1971) di bawah tema: "Disuruh ke dalam dunia". Pengarahan ini tidak bisa dilepaskan dari pengaruh persidangan raya WCC di tahun 1968 yang memfokuskan diri dari persoalan dunia seperti kemiskinan dan penindasan serta tanggung jawab gereja terhadap persoalan itu. ${ }^{35}$

PGI berkomitmen untuk ikut mengambil bagian dalam upaya menyelesaikan segala persoalan yang dihadapi di negeri ini. Hal ini dibuktikan oleh banyaknya tokoh Kristen yang merumuskan pemikirannya terhadap masalah sosial yang tengah dihadapi oleh bangsa ini semisal T. B. Simatupang yang membahas mengenai mengenai partisipasi gereja dalam pembangunan bangsa Indonesia dalam bingkai teologis sedangkan Andreas A. Yewangoe membahas situasi kemajemukan agama di Indonesia.

Tokoh pertama, T. B. Simatupang (mantan Ketua PGI nonteolog) dalam rangka pembangunan nasional sebagai pengamalan Pancasila itu Simatupang mengatakan bahwa orang Kristen di Indonesia bukan orang asing karena itu masalah perjuangan, dan

35. Timo, “Nasionalisme Indonesia," 74-75. 
pergumulan bangsa ini juga merupakan pergumulan orang Kristen. Di samping itu juga, dalam proses pembangunan harus dilihat dari bagian mengamalkan Pancasila namun juga harus diletakkan dalam tolak ukur Kerajaan Allah. ${ }^{36}$

Tokoh kedua, Andreas A. Yewangoe, (mantan Ketua Umum PGI). Yewangoe dalam bukunya Agama dan Kerukunan menjelaskan selama Islam berada di jazirah Arab, di mana Islam berkuasa tanpa ada yang mengganggu-gugat, maka persatuan Islam dan persatuan Arab sama artinya. Tetapi permasalahan baru muncul ketika Islam keluar dari negeri Arab dan berada dalam suatu masyarakat dengan derajat heterogenitas yang tinggi. Bagaimana Islam bertindak sebagai yang memperkuat kebangsaan tanpa mengabaikan pula kekuatankekuatan lain yang ada di situ? Barangkali itulah salah satu akar persoalan terjadinya polarisasi antara golongan Islam dan golongan Nasionalis. ${ }^{37}$ Golongan Islam memperjuangkan agenda untuk memasukkan hukum syariat Islam dalam sebuah otonomi daerah, Yewangoe berpandangan kewajiban melakukan syariat Islam itu merupakan kewajiban spesifik bagi umat Islam dan bukan diberlakukan secara umum dalam konteks masyarakat yang pluralis. $^{38}$

36. Andreas A. Yewangoe, Theologia Crucis di Asia PandanganPandangan Orang Kristen Asia mengenai Penderitaan dalam Kemiskinan Dan Keberagamaan di Asia (Jakarta: BPK Gunung Mulia, 1996), 284-287.

37. Yewangoe, Agama dan Kerukunan, 20

38. Wawancara Andreas A. Yewangoe, 11 Oktober 2019 pukul 14.0016.05 WIB 
Mengenai kehadiran HTI, Yewangoe melihat bahwa gerakan khilafah adalah gerakan politik yang sama sekali mengabaikan latar belakang sejarah perjuangan bangsa ini untuk menjadi satu bangsa. Oleh itu Yewangoe mengatakan kalau rumah bersama itu sekarang digerogoti oleh anasir anti-Pancasila maka kita harus mengusir anasir pengacau itu. ${ }^{39}$

Terakhir mengenai kehadiran faham Wahabisme. Yewangoe mengungkapkan bahwa sejak dulu kehidupan keberagamaan di Indonesia sangat harmonis dan menjunjung nilai toleransi. Namun belakangan situasi pun berubah sejak kehadiran kelompok agama yang berwatak radikal dan fundamental. ${ }^{40}$ Situasi inilah mengancam persatuan dan kesatuan Indonesia sebagai bangsa yang pluralis. Menyingkapi penyebaran faham Wahabisme, Yewangoe menganjurkan agar (1) sejak dini anak-anak sudah harus diinsafkan bahwa mereka hidup dalam sebuah masyarakat yang majemuk (2) pengetahuan sejarah Indonesia harus ditanamkan sejak dini bahwa Indonesia tidak jadi begitu saja, tetapi melalui proses yang mengorbankan nyawa dan air mata. ${ }^{41}$

39. Andreas A. Yewangoe, Allah Mengizinkan Manusia Mengalami Diri-Nya Pengalaman dengan Allah dalam konteks Indonesia yang Berpancasila (Jakarta: BPK Gunung Mulia, 1996), 194

40. Ms, "Junjung Tinggi Kemanusiaan dalam Menyikapi Konflik dan Kekerasan Berlatar Belakang Agama," Berita Oikoumene, November 2012, 13

41. Ms, "Junjung Tinggi Kemanusiaan," 107 


\section{Bagaimana Kedepannya?}

Apa yang harus kita lakukan kedepannya merupakan tugas tanggung jawab kita semua warga negara di Indonesia. Tantangan bagi agama-agama di masa kini semakin berat. Apalagi dengan kehadiran seperti gerakan transnasional seperti khilafah dan faham Wahabisme yang belakangan ini meresahkan masyarakat Indonesia. Gerakan khilafah global merupakan gerakan yang tersistematis menjadikan negara Indonesia menganut sistem khilafah yang berdasarkan hukum dan ajaran Islam dan menolak konsep negara beserta ideologinya. Jika khilafah ditegakkan maka akan berpotensi terjadinya perang saudara di negara kita. Gerakan khilafah global jelas gerakan politik yang terlarang dan tidak etis dipaksakan dalam konteks kemajemukan di Indonesia. Kemajemukan merupakan realitas yang harus dipandang positif karena ini akibat dari proses globalisasi dalam peradaban manusia moderen. Sedangkan faham Wahabisme bisa membawa penganutnya menjadi radikal dan membuka peluang menjadi pelaku teroris sebab yang berbeda darinya dianggap kafir dan halal untuk diperangi. Dalam pandangan teologisnya Wahabisme merasa ajaran Islam yang dianutnya murni dan paling benar karena belum dipengaruhi oleh budaya lokal, maupun perkembangan iptek. Oleh karena itu, organisasi keagamaan harus bekerjasama dengan pemerintah agar menghimbau seluruh masyarakat kita untuk menolak dan tidak mengikuti gerakan transnasional khilafah global dan faham Wahabisme yang bertentangan dengan semangat Pancasila, UUD'45, NKRI, dan 
Bhinneka Tunggal Ika. Tugas para pemimpin umat beragama (Islam) mengingatkan secara intensif umatnya untuk tidak terjerumus dan mengikuti ajaran dan gerakan aktivitas politik tersebut. Islam yang ada di Indonesia adalah Islam yang sudah dinusantarakan. Islam Nusantara bukan mazhab baru dalam Islam, namun ini ada ciri khas Islam di Indonesia. Islam sejatinya adalah agama Rahmatan lil'alamin yakni Islam yang lapang, toleran, tidak mendendam, tidak mengkafirkafirkan sesama, tidak menyetujui adanya kekerasan, permusuhan, menghormati kemajemukan sebagai realita dari nasionalisme. Nasionalisme itu sebagai bagian dari keberimanan umat Islam serta menjadikan Indonesia negara yang damai (Darussalam). Maka, semua warga negara beserta lembaga pemerintah dan organisasi keagamaan yang terkait seperti, PBNU, PP Muhammadiyah, PGI, KWI, WALUBI, PHDI, dan sejenisnya bertanggungjawab melindungi segenap tanah air dan mempertahankan kedaulatan NKRI dari serangan di luar maupun di dalam negara Indonesia sendiri yang berusaha untuk memecahbelah bangsa ini. Sebelumnya, melalui Kementeriaan Agama RI Lukman Hakim, pernah mengeluarkan kebijakan untuk melarang pemuka agama yang tidak cinta NKRI dan Pancasila untuk berceramah di mesjid-mesjid dan karenanya ini sangat dibutuhkan kerjasama dari jamaah muslim setempat agar tidak memberikan ruang atau panggung bagi pemuka agama tersebut untuk berceramah.

Kemudian, agama-agama yang selama ini menghayati kehidupan dalam konteksnya masing-masing semakin menyadari 
bahwa keberadaan agama lain mestilah diterima sebagai kenyataan dan ditanggapi secara positif. Kesadaran akan besarnya tantangan yang dihadapi umat beragama mendorong proses saling mendekatkan diri (konvergensi) yang sering juga disebut proses pertemuan beragama (encounter)..$^{42}$ Oleh karenanya setiap agamaagama di Indonesia tidak boleh merasa menjadi agama superior di atas agama-agama dan masyarakat beragama tidak boleh melakukan pola penyiaran agama yang bersifat "memaksa" karena itu akan melukai sesama warga Indonesia yang berbeda keyakinan dengan kita.

Di samping itu, perda-perda bersyariat harus dihapuskan dari sistem otonomi daerah karena Indonesia bukan negara yang diatur berdasarkan agama tertentu namun negara kita adalah negara Pancasila. Singkatnya, demi menjaga keutuhan NKRI, di masa sekarang dan yang akan datang maka kebhinnekaan harus semakin diperkuat dan jalannya demokrasi harus diimbangi oleh penegakkan hukum yang sesuai dengan norma-norma yang berlaku.

Konvergensi agama ditandai dengan semakin digiatkan dialog antar umat beragama di semua aras, baik lokal, nasional, maupun internasional. Tujuannya bukan untuk menyamakan ajaran, melainkan untuk saling mengenal pokok-pokok ajaran masingmasing dan menghargainya sebagai bagian dari respons umat beragama menyikapi masalah-masalah kehidupan. Pertemuan antar umat beragama yang semakin intensif memperkuat tumbuhnya

42. Sitompul, "Gereja, Agama dan Globalisasi," 13-14. 
kesadaran global: semakin disadari bahwa semua umat beragama sedang berjuang mengatasi tantangan bersama. Kemiskinan dan ketidakadilan adalah menyakitkan bagi semua orang, tak peduli apa agamanya. ${ }^{43}$ Melihat akan realitas yang ada, orang Kristen dipanggil bukan untuk membangun kesejahteraan dirinya semata. Kita dipanggil untuk mewujudkan kerajaan Allah melalui upaya menegakkan keadilan membebaskan orang tertindas dan lemah, serta mengentaskan kemiskinan (Bdk. Luk. 4:18-19). Warga gereja untuk itu perlu terus memupuk solidaritas terhadap orang-orang miskin dan lemah. Pelayanan kita tidak hanya untuk menambah jumlah warga gereja (kuantitatif), melainkan juga meningkatkan kehidupan bersama (kualitatif). ${ }^{44}$

Keikutsertaan orang Kristen membangun bangsa juga pertanda sifat misioner gereja. Kita juga perlu mengembangkan sikap kritis agar tahu menimbang mana yang baik dan mana yang jahat, dan mengembangkan peranan aktif dan antisipatif di dalam kehidupan bernegara. Membangun negara yang adil dan makmur adalah bagian integral dari panggilan Kristiani kita. ${ }^{45}$ Selain itu PGI pernah membuat kebijakan nasional di bidang ekonomi global. Keputusan yang dikeluarkan berbunyi: "Gereja turut mengkritisi kebijakan perekonomian pemerintah, yaitu pemulihan ekonomi jangan sampai mengulangi sistem dan struktur ekonomi pada masa lalu yang hanya

43. Sitompul, “Gereja, Agama dan Globalisasi," 14.

44. Sitompul, "Warga Gereja dalam Kehidupan Bernegara", 35.

45. Sitompul, "Warga Gereja dalam Kehidupan Bernegara”, 35. 
menguntungkan sebagian kecil orang dan mengabaikan bagian yang paling besar. Gereja harus senantiasa menekankan perlunya keberpihakan kepada pada upaya-upaya memajukan perekonomian rakyat kecil ..." ${ }^{46}$

\section{Kesimpulan}

Fakta sejarah memperlihatkan jauh sebelum kemerdekaan Indonesia itu ada Indonesia (Nusantara) adalah bangsa yang majemuk. Kemajemukan merupakan sumber kekayaan dan identitas atau jati diri bangsa kita. Melalui lahirnya Pancasila semakin memperkokoh semangat nasionalisme di bangsa ini. Dengan ini ditegaskan di masa kini bahwa tidak perlu mempersoalkan sistem ideologi negara Indonesia sebab persoalan kebangsaan sudah selesai sebab ini sudah menjadi kesepakatan bersama di antara tokoh pendiri bangsa. Sebagai bentuk antisipasi dengan kehadiran HTI dan Wahabisme jangan biarkan cara beragama di Indonesia yang sebelum sangat toleran terhadap agama lain diubah menjadi beragama yang menindas agama lain di Indonesia. Maka beragama di Indonesia semestinya mengintegrasikan antara iman dan nasionalisme sebagai bentuk kecintaannya terhadap republik ini.

Terkait dengan masalah sosial yang tengah di hadapi oleh bangsa ini hal tersebut merupakan tugas tanggungjawab seluruh komponen

46. Ranto G. Simamora, Misi Kemanusian dan Globalisasi Teologi Misi dalam Konteks Globalisasi (Bandung: Ink Media, 2006), 75. 
bangsa karena itu kita harus memperjuangkan terwujudnya nilai-nilai kemanusiaan dan keadilan sosial yang berasaskan Pancasila.

\section{Bibliografi}

Abdillah, Masykuri. Islam dan Dinamika Sosial Politik. Jakarta: PT Gramedia Pustaka Utama, 2011.

Aritonang, Jan S. Sejarah Perjumpaan Kristen dan Islam di Indonesia. Jakarta: BPK Gunung Mulia, 2006.

Daulay, Richard. Kekristenan dan Politik. Jakarta: Waskita, 2011.

Fachrudin, Azis Anwar. Polemik Tafsir Pancasila. Yogyakarta: CRCS (Center for Religious and Cross-cultural Studies) Program Studi Agama dan Lintas Budaya Sekolah Pascasarjana Lintas Disiplin UGM, 2018.

Geovanie, Jeffrie. Civil Religion Dimensi Sosial Politik Islam. Jakarta: PT Gramedia Pustaka Utama, 2013.

Ghazali, Abd Moqsith. "Demistifikasi Kepemimpinan Politik Muhammad SAW". dalam Buletin Postra Islam, Politik, dan Demokrasi. Jakarta: Institute for Social Institutions Studies (ISIS), Juli - Agustuts, 2002.

Hutauruk, M. Gelora Nasionalisme Indonesia. Jakarta: Erlangga, 1984.

Jonkennedi. Gerakan Hizbut Tahrir dan Realitas Politik Islam Kontemporer di Indonesia. Dakwah dan Komunikasi Jurnal Komunika Vol. 6 No.1 Januari-Juni 2012.

Ngelow, Zakharia J. Kekristenan dan Nasionalisme Perjumpaan Umat Kristen Protestan dengan Pergerakan Nasional Indonesia 1900-1950. Jakarta: BPK Gunung Mulia, 1996.

Nurcahyo, Y. Ari. "Pascanasionalisme, Pascalndonesia Meneropong Masa Depan Nasionalisme." dalam Meneropong Indonesia 2020 Pemikiran dan Masalah Kebijakan. Jakarta: Soegeng Sarjadi Syndicated, 2004.

Rahmat, loanes. Di Tengah Arus Fundamentalisme dalam Gereja, dalam Fundamentalisme Agama-Agama dan Teknologi. Jakarta: BPK Gunung Mulia, 1992. 
Shidqi, Ahmad. Respons Nahdlatul Ulama (NU) terhadap Wahabisme dan Implikasinya bagi Deradikalisasi Pendidikan Islam. Jurnal Pendidikan Islam, Volume II/1 Juni 2013.

Simamora, Ranto G. Misi Kemanusian dan Globalisasi Teologi Misi dalam Konteks Globalisasi. Bandung: Ink Media, 2006.

Simatupang, T. B. Iman Kristen dan Pancasila. Jakarta: BPK Gunung Mulia, 1985.

Sitompul, Einar M. "Gereja, Agama dan Globalisasi." dalam Perjalanan Sarat Muatan 1-65 Tahun Pdt. Dr. Einar $M$ Sitompul. Jakarta: Unit Publikasi dan Informasi Sekolah Tinggi Teologi Jakarta, 2014.

. "Warga Gereja dalam Kehidupan Bernegara." dalam Perjalanan Sarat Muatan Buku 1 - Pdt. Dr. Einar Sitompul. Jakarta: Unit Publikasi dan Informasi Sekolah Tinggi Teologi Jakarta berkerjasama dengan HKBP Menteng, 2014.

Solaiman, Antie. "Teologi dan Nation Building: Gereja dan Pembenahan Sosial." dalam Peran Kristen dalam Membangun Masyarakat Sipil. Diedit oleh Victor Silaen. Jakarta: Pustaka Tangga, 2003.

Timo, Ebenhaizer Nuban. Nasionalisme Indonesia: Sebuah Kajian Antropologis-Historis mengenai Partisipasi Gereja dalam Nasionalisme Indonesia Pasca Pilpres 2014, Jurnal Humaniora Yayasan Bina Darma, Diskursus III/3, September 2014.

Weiden, W. Van Der. "Kritik Sosial dari Nabi-Nabi Israel." dalam Aspek-Aspek Teologi Sosial ed. J. B. Banawiratma Yogyakarta: Kanisius, 1988.

Yewangoe, Andreas A. Agama dan Kerukunan. Jakarta: BPK Gunung Mulia, 2002. . Allah Mengizinkan Manusia Mengalami DiriNya Pengalaman dengan Allah dalam konteks Indonesia yang Berpancasila, Jakarta: BPK Gunung Mulia, 2018. - Theologia Crucis Di Asia PandanganPandangan Orang Kristen Asia mengenai Penderitaan dalam Kemiskinan Dan Keberagamaan di Asia. Jakarta: BPK Gunung Mulia, 1996. 


\section{Bahan Ajar}

Daulay, Richard. Keterlibatan Umat Kristen di Tengah Kehidupan Sosial Politik di Indonesia. Makalah: Kuliah Umum STT Cipanas, 2012.

\section{Majalah}

Ms. "Junjung Tinggi Kemanusiaan dalam Menyikapi Konflik dan Kekerasan Berlatar Belakang Agama." Berita Oikoumene, November 2012.

\section{Wawancara}

Wawancara Andreas A. Yewangoe, 11 Oktober 2019 pukul 14.00-16.05 WIB. 